\title{
The Role of Nitrogen Fertilizers in Sugarcane Root Biomass under Field Conditions
}

\author{
Rafael Otto ${ }^{1}$, Henrique Coutinho Junqueira Franco ${ }^{2}$, Carlos Eduardo Faroni ${ }^{3}$, \\ André Cesar Vitti ${ }^{4}$, Emídio Cantidio Almeida de Oliveira ${ }^{5}$, Renata Alcarde Sermarini ${ }^{6}$, \\ Paulo Cesar Ocheuze Trivelin 7 \\ ${ }^{1}$ Department of Soil Science, Luiz de Queiroz College of Agriculture, University of São Paulo, \\ Piracicaba, Brazil \\ ${ }^{2}$ Brazilian Bioethanol Science and Technology Laboratory (CTBE), Rua Giuseppe Maximo Scolfaro, \\ Campinas, Brazil \\ ${ }^{3}$ Sugarcane Research Center (CTC), Piracicaba, Brazil \\ ${ }^{4}$ São Paulo Agency of Agribusiness and Technology (APTA), Piracicaba, Brazil \\ ${ }^{5}$ Federal Rural University of Pernambuco (UFRPE), Recife, Brazil \\ ${ }^{6}$ Department of Exact Sciences, Luiz de Queiroz College of Agriculture, University of São Paulo, \\ Piracicaba, Brazil \\ ${ }^{7}$ Center for Nuclear Energy in Agriculture, University of São Paulo, Piracicaba, Brazil \\ Email: rotto@usp.br, henrique.franco@bioetanol.org.br, carlos.faroni@ctc.com.br, acvitti@apta.sp.gov.br, \\ emidio@uast.ufrpe.br, ralcarde@usp.br, pcotrive@cena.usp.br
}

Received 20 October 2014; revised 23 November 2014; accepted 30 November 2014

Copyright (C) 2014 by authors and Scientific Research Publishing Inc.

This work is licensed under the Creative Commons Attribution International License (CC BY).

http://creativecommons.org/licenses/by/4.0/

(c) (i) Open Access

\section{Abstract}

Sugarcane is used worldwide for sugar, ethanol and energy production. In Brazil, the shift from burned to unburned harvest systems resulted in increases in nitrogen fertilization rates, which can impact root architecture and biomass. The expectation is also an increase in sugarcane biomass. The study hypothesized that high $\mathrm{N}$ rates applied to sugarcane fields increases root growth and $\mathrm{N}$ stored in roots, promoting higher biomass and $\mathrm{N}$ accumulated in shoots. Two experiments were set up in Southeastern Brazil, on a Typic Kandiudox (TK) and Rhodic Eutrudox (RE). Four treatments were studied 1) $\mathrm{N}$ application in the plant-cane ( 0 and $120 \mathrm{~kg} \cdot \mathrm{ha}^{-1} \mathrm{~N}$ ) and 2) $\mathrm{N}$ application in the ratoon ( 0 and $150 \mathrm{~kg} \cdot \mathrm{ha}^{-1} \mathrm{~N}$ ). The shoot biomass and the root density (by the core method up to $0.6 \mathrm{~m}$ ) were evaluated over the first ratoon crop cycle, and the $\mathrm{N}$ content in those compartments was also examined. There was no carry over effect on $\mathrm{N}$ applied at planting in root and shoot biomass in the ratoon crop cycle. At the $\mathrm{RE}$ site, the ratoon $\mathrm{N}$ fertilization increased root density in the superficial soil layer $(0-0.2 \mathrm{~m})$ and close to the plants $(<0.3 \mathrm{~m})$. The effect of $\mathrm{N}$ addi- 
tion on root biomass, and biomass and $\mathrm{N}$ accumulated in shoot was limited in both sites. Increasing $\mathrm{N}$ rates in unburned sugarcane fields do not consistently increases root and shoot biomass under Brazilian field conditions.

\title{
Keywords
}

\author{
Root System, Ratoon, Shoot, Root: Shoot Ratio
}

\section{Introduction}

Sugarcane (Saccharum spp.) is an important crop for bioenergy production in order to reduce green house gas emissions and fossil fuel consumption [1]. Brazil is the world leader in sugarcane production, with a cultivated area of 9.7 million hectares of the total 26 million hectares cultivated worldwide [2].

Sugarcane productivity may be influenced by root system properties because of their effects on the supply of belowground resources, gas exchange and assimilation and also the carbon economy of the plant and partitioning of assimilate to yield components [3]. Many aspects of sugarcane physiology are still poorly understood, including the root-shoot relationships that ultimately affect yield. Studies on sugarcane roots lag well behind those on other crops, in part to the large plant stature and long crop cycle [4]. Very little is currently known about the root architecture of this crop [5].

Nitrogen fertilizer additions are an important contributor to productivity in farming systems. In Brazil, $\mathrm{N}$ fertilizer is applied at planting in rates varying from 40 to $80 \mathrm{~kg} \cdot \mathrm{ha}^{-1} \mathrm{~N}$ (usually incorporated in the furrow), while in the ratoon the rates are substantially higher reaching 100 to $150 \mathrm{~kg} \cdot \mathrm{ha}^{-1} \mathrm{~N}$ (surface applied or incorporated). In Brazil the mechanically harvested area is increasing, leading to straw accumulation on soil surface. Under this system higher $\mathrm{N}$ rates have been recommended as compared to the burned system [6], which can modify the pattern of belowground and aboveground components accumulation in sugarcane.

Plants can modify rooting patterns, i.e. an increase in the local formation and growth of lateral roots in response to soil nutrient heterogeneity [7]. Soil resource heterogeneity, particularly nitrogen, stimulates distribution of plant hormones that alters local root growth thorugh root initiation, elongation, and branching [8]. Also, application of fertilizers can alter root architecture and growth. Localized application of ammonium, for example, could stimulate root proliferation and improve the crop capacity to explore soil [9] [10]. Root responses to localized nutrient supply play a crucial role in nutrient capture by crops and thus improve nutrient-use efficiency [11]. Graminaceous species appeared to have a better capacity to increase root growth to adapt to nutrient deficiency than leguminous species [12].

The overall findings of previous research is that $\mathrm{N}$ addition modify the rooting patterns, as demonstrated in crops such as corn [13]-[15] and barley [16]. For sugarcane, studies leading with effects of $\mathrm{N}$ addition on root system are limited to the plant crop cycle [17]-[19], despite most area cultivated with sugarcane refers to the ratoon crop. Previous studies show that $\mathrm{N}$ fertilization increases $\mathrm{N}$ stored in root system with a positive effect on sugarcane yield in the year of application and also in the following year [20]. The authors called this effect as "residual effect" of $\mathrm{N}$ fertilization. This phenomenon is expected to occur since sugarcane is a semi-perenial crop which depends of nutritional reserves in underground components to promote a vigorous regrowth.

This study hyphotisized that high $\mathrm{N}$ rates will affect root system architecture and increase reserves of $\mathrm{N}$ in underground components, with further effect in shoot biomass and $\mathrm{N}$ accumulation. The goal of this study was to evaluate the effects of $\mathrm{N}$ fertilization at planting (residual effect) and for the ratoon on 1) dynamics of sugarcane root biomass over the ratoon crop cycle; 2) $\mathrm{N}$ accumulation in the aboveground and belowground components of the crop.

\section{Material and Methods}

The experiments were set up at two sites in Jaboticabal, São Paulo, Brazil, at Santa Adelia Mill (SA site; 21 ${ }^{\circ} 19^{\prime}$ 98"S and 48 $18^{\circ} 03^{\prime \prime} \mathrm{W}, 600 \mathrm{~m}$ of altitude) and Sao Martinho Mill (SM site; $21^{\circ} 15^{\prime} \mathrm{S}$ and $48^{\circ} 18^{\prime} \mathrm{W}, 580 \mathrm{~m}$ of altitude), where the variety SP81 3250 of sugarcane (Saccharum spp.) is grown. Both sites have been cultivated with sugarcane for at least 30 years before trials establishment. At the SA site, sugarcane has been burned before 
harvest until one year before experiment establishment; at SM site, unburned harvesting was performed in the last seven years before experiment establishment.

The sugarcane fields were established on February 2005 on SM site and on April 2005 on SA site. The tillage adopted previously of sugarcane establishment at the SA site was as follows: application of herbicide, distribuition of $2 \mathrm{t} \cdot \mathrm{ha}^{-1}$ of lime, deep plowing (at a depth of approximately $0.4 \mathrm{~m}$ ), harrowing (twice, at a depth of approximately $0.25 \mathrm{~m}$ ) and furrowing. At $\mathrm{SM}$, the tillage operation sequence was herbicide application, chisel plowing (at approximately a $0.35 \mathrm{~m}$ deep) and furrowing. No lime was applied following soil chemical analysis.

Furrows were dug at depths of approximately $0.35 \mathrm{~m}$, and cuttings distributed on the furrow allowing distribution of 15 buds per meter of furrow. Additionaly was applied $120 \mathrm{~kg} \cdot \mathrm{ha}^{-1}$ of $\mathrm{P}_{2} \mathrm{O}_{5}$ and $120 \mathrm{~kg} \cdot \mathrm{ha}^{-1}$ of $\mathrm{K}_{2} \mathrm{O}$, in the form of triple superphosphate and potassium chloride, respectively. Before the cuttings were covered with soil, insecticide and nematicide were applied. The cuttings were covered with a $0.1 \mathrm{~m}$ soil layer.

At site SA, the soil is a Typic Kandiudox, and at SM, Rhodic Eutrudox [21]. Typic Kandiudox and Rhodic Eutrudox will be refered thereafter as TK or RE throughout the text. Soils were sampled in July 2006 for chemical, physical and hydraulic characterization in profile horizons down to $1.5 \mathrm{~m}$. Disturbed samples were used for chemical and granulometric analysis, and three undisturbed samples per horizon were used for soil hydraulic and bulk density measurements. The soil chemical, physical and hydraulic characterization is shown in Table 1 .

Two treatments were applied at planting (performed on February 22 to 24, 2005 at RE site and April 02 to 04, 2005 at TK site) of the sugarcane fields: 0 and $120 \mathrm{~kg} \cdot \mathrm{ha}^{-1} \mathrm{~N}$ as urea, applied at the bottom of the furrow, in the random complete blocks experimental design, with four repetitions. After the first harvest (performed on July 26, 2006 at TK and on August 10, 2006 at RE), the plots were subdivided and applied the treatments of 0 and 150 $\mathrm{kg} \cdot \mathrm{ha}^{-1} \mathrm{~N}$. The four treatments will be designed thereafter as $0-0,0-150,120-0$, and $120-150$. The measurements were performed only during the first ratoon crop cycle, to determine the residual $\mathrm{N}$ effect from the plant crop on the ratoon and the effect of $\mathrm{N}$ addition during the ratoon cycle. In the ratoon crop cycle each experimental plot comprised 12 furrows spaced $1.5 \mathrm{~m}$ apart that were $15 \mathrm{~m}$ long.

Fertilizers were applied to the ratoon on the $1^{\text {st }}$ and $2^{\text {nd }}$ of October 2006 in the TK and RE sites, respectively. The fertilizers were applied manually with the most homogeneous distribution as possible in one side of the sugarcane ratoon, without any incorporation. At TK, the $\mathrm{N}$ source was ammonium sulfate ( $21 \% \mathrm{~N}$ and $24 \% \mathrm{~S}$ ), so that the treatments with $150 \mathrm{~kg} \cdot \mathrm{ha}^{-1} \mathrm{~N}$ applied to the ratoon also received $171 \mathrm{~kg} \cdot \mathrm{ha}^{-1} \mathrm{~S}$. A mixture of ammonium sulfate and ammonium nitrate $(32 \% \mathrm{~N})$ was used at $\mathrm{RE}$, supplying $57 \mathrm{~kg} \cdot \mathrm{ha}^{-1}$ of $\mathrm{S}$ in all $\mathrm{N}$ rates

Table 1. Chemical ${ }^{\mathrm{a}}$, physical ${ }^{\mathrm{b}}$ and hydraulic ${ }^{\mathrm{c}}$ characterization of Typic Kandiudox (TK) and of Rhodic Eutrudox (RE).

\begin{tabular}{|c|c|c|c|c|c|c|c|c|c|c|c|c|c|c|c|c|}
\hline Soil horizon & pH & SOM & $\mathbf{P}$ & $\mathbf{K}$ & Ca & Mg & Al & $\mathbf{H}+\mathbf{A l}$ & CEC & BS & Sand & Silt & Clay & $\boldsymbol{\Theta}_{\mathrm{fc}}$ & $\boldsymbol{\Theta}_{\mathrm{pwp}}$ & Bd \\
\hline \multirow[t]{2}{*}{ m } & $\mathrm{H}_{2} \mathrm{O}$ & $\mathrm{g} \cdot \mathrm{kg}^{-1}$ & $\mathbf{m g} \cdot \mathbf{k g}^{-1}$ & & & \multicolumn{3}{|c|}{$\mathrm{mmol}_{\mathrm{C}} \cdot \mathrm{kg}^{-1}$} & & \multicolumn{2}{|l|}{$\%$} & \multicolumn{2}{|l|}{$\mathbf{g} \cdot \mathbf{k g}^{-1}$} & \multicolumn{2}{|c|}{$\mathbf{m}^{3} \cdot \mathbf{m}^{-3}$} & $\mathbf{k g} \cdot \mathrm{m}^{-3}$ \\
\hline & \multicolumn{16}{|c|}{ Typic Kandiudox } \\
\hline Ap $(0-0.15 m)$ & 6.3 & 23 & 10 & 3.6 & 18 & 13 & 0 & 17 & 51.6 & 67 & 661 & 54 & 285 & 0.26 & 0.15 & 1305 \\
\hline $\mathrm{A}_{2}(0.16-0.37 \mathrm{~m})$ & 6.0 & 16 & 11 & 2.2 & 9 & 5 & 2 & 18 & 34.2 & 47 & 651 & 53 & 296 & 0.23 & 0.17 & 1460 \\
\hline BA $(0.38-0.56$ m) & 5.1 & 11 & 3 & 1.2 & 2 & 1 & 8 & 31 & 35.2 & 12 & 603 & 50 & 347 & 0.26 & 0.19 & 1391 \\
\hline $\mathrm{B}_{\mathrm{w} 1}(0.57-0.96 \mathrm{~m})$ & 5.6 & 8 & 1 & 0.9 & 3 & 1 & 3 & 20 & 24.9 & 20 & 583 & 46 & 371 & 0.23 & 0.17 & 1208 \\
\hline \multirow[t]{2}{*}{$\mathrm{B}_{\mathrm{w} 2}(0.97-1.50 \mathrm{~m})$} & 5.9 & 7 & 1 & 3.5 & 2 & 1 & 0 & 9 & 15.5 & 42 & 578 & 53 & 369 & 0.24 & 0.16 & 1244 \\
\hline & \multicolumn{16}{|c|}{ Rhodic Eutrudox } \\
\hline Ap $(0-0.37 m)$ & 5.4 & 30 & 36 & 1.7 & 29 & 9 & 1 & 59 & 98.7 & 40 & 135 & 227 & 638 & 0.45 & 0.34 & 1299 \\
\hline $\mathrm{Bw}_{1}(0.38-0.60 \mathrm{~m})$ & 5.5 & 15 & 6 & 0.2 & 22 & 6 & 0 & 30 & 58.2 & 48 & 117 & 195 & 688 & 0.43 & 0.31 & 1330 \\
\hline $\mathrm{Bw}_{2}(0.61-0.98 \mathrm{~m})$ & 6.0 & 10 & 2 & 0.2 & 20 & 5 & 0 & 23 & 48.2 & 52 & 117 & 170 & 713 & 0.39 & 0.28 & 1318 \\
\hline $\mathrm{Bw}_{3}(0.99-1.50 \mathrm{~m})$ & 6.8 & 8 & 1 & 0.2 & 16 & 4 & 0 & 19 & 39.1 & 51 & 112 & 175 & 713 & 0.39 & 0.27 & 1375 \\
\hline
\end{tabular}

${ }^{\mathrm{a}} \mathrm{SOM}$, soil organic matter by the Walkey-Black method; $\mathrm{P}, \mathrm{K}$, Ca, and $\mathrm{Mg}$, extraction with ion exchange resin; Al extractable with $1 \mathrm{~N}$ KCl; $\mathrm{H}+\mathrm{Al}$ using SMP buffer solution; CEC, cation exchange capacity; BS, base saturation. Analysis following [22]: 'sand, silt and clay obtained by the pipette method; Bd, bulk density obtained by the volumetric rings method [23]. ' Undisturbed soil samples were wetted to saturation and afterwords submitted to matric potentials using a pressure plate equivalent to the field capacity $-\mathrm{FC}(\psi=-10 \mathrm{kPa})$ and to the permanent wilting point $-\mathrm{PWP}(\psi=-1500$ $\mathrm{kPa})$ to determine the soil moisture at $\mathrm{FC}\left(\Theta_{\mathrm{fc}}\right)$ and at the PWP $\left(\Theta_{\mathrm{pwp}}\right)[24]$. 
Potassium was also applied after the first harvest to all of the plots at a rate of $150 \mathrm{~kg} \cdot \mathrm{ha}^{-1} \mathrm{~K}_{2} \mathrm{O}$ in the form of potassium chloride.

Biomass measurements of roots and shoots were performed in the ratoon crop cycle; additionally, the root biomass was also evaluated at the cane plant harvest. The measurements were performed at 0, 145, 225, 288 and 349 days after harvest (dah) at TK and at 0, 124, 211, 274 and 369 dah at RE, in the months of December 2006, March 2007, May 2007 and July 2007 (TK) or August 2007 (RE). The last measurement coincided with the ratoon harvest. The underground stem component (stool) measurements were conducted only in the last period.

For shoot measurement the canes present in two-meter furrow segments were harvested at randomly chosen positions in each block, and the mass of fresh matter obtained in a field scale (0.02 kg precision). Root samples were obtained on the same area used previously for shoot measurements, using a root sampling probe (SONDATERRA $^{\circledR}$ ) with a $5.5 \mathrm{~cm}$ internal diameter, down to a depth of $0.6 \mathrm{~m}$, divided in $0.2 \mathrm{~m}$ layers (Figure 1). A previous study comparing the root biomass obtained by the probe and monoliths in the cane plant harvest in these areas showed probe provided reliable estimations of sugarcane root biomass [25]. To evaluate the stool biomass, the entire underground stem components present in one meter of the furrows were collected.

At the field sites, shoot samples were crushed through a forage crusher and a subsample was hermetically sealed and taken to the laboratory. Soil plus root samples were sieved in the field using $2 \mathrm{~mm}$ sieves, and the roots were placed into plastic bags. The underground stem components were carefully separated from all adhered soil particles and root pieces. In the laboratory, the roots were washed in water through $1 \mathrm{~mm}$ sieves, and the stool was washed in water to remove the soil clinging to them. All the samples were then oven dried under forced circulation at $65^{\circ} \mathrm{C}$. After obtaining the dry weight, the samples were crushed in a Willey type mill, and the $\mathrm{N}$ content was determined by Kjeldahl method [26].

Additionally, the number of tillers per 30 meters of each plot was counted to obtain the number of tillers per hectare. The product of the dry mass of each tiller and the number of tillers per hectare was used to estimate the dry mass of shoot per hectare. The stool mass per hectare was obtained from the product of the dry mass obtained in a meter of furrow and the length of furrows per hectare, considering $1.5 \mathrm{~m}$ space between furrows. The root density (RD) in each position (A, B, or C, Figure 1) was obtained as follow:

$$
\mathrm{RD}\left(\mathrm{g} \cdot \mathrm{dm}^{-3}\right)=(\text { root dry mass }(\mathrm{g}) / 2 \text { samples per local }) / \text { soil volume sampled by probe }\left(0.4751 \mathrm{dm}^{-3}\right)
$$

The root biomass (RB) was calculated as follows:

$$
\mathrm{RB}\left(\mathrm{t} \cdot \mathrm{ha}^{-1}\right)=\left[\mathrm{RD}_{\mathrm{A}} \cdot(0.3 / 1.5)+\mathrm{RD}_{\mathrm{B}} \cdot(0.6 / 1.5)+\mathrm{RD}_{\mathrm{C}} \cdot(0.6 / 1.5)\right] \cdot 10.000 \cdot \mathrm{D}
$$

In which the remaining variables means: $\mathrm{D}$, depth of sampling $(\mathrm{m})$, equal to $0.2 \mathrm{~m}$ for each soil layer. The total root biomas $(<0.6 \mathrm{~m})$ was obtained as the sum of root biomass obtained in each soil layer.

These measurements were repeated in all periods described above, randomly choosing the sampling sites inside each plot and taking care not to conduct the measurements in places that were previously sampled.

To obtain the climatological water balance the evapotranspiration potential $\left(\mathrm{ET}_{0}\right)$ was calculated using the Penman-Monteith equation with the parameterizations proposed by [27]. The crop evapotranspiration (ETc) was obtained by multiplying the $\mathrm{ET}_{0}$ by the crop coefficient (Kc) for the different growth stages, as described in [27]. Weather data were obtained from weather stations situated less than $2 \mathrm{~km}$ from the experimental areas, and daily rainfall data were obtained through rain gauges installed in the experimental sites.

Considering the lack of independence of root samples collected in the same plot each date, the results of root density per soil layers and distance from plants were presented as mean values and standard deviation. The ANOVA was performed for the data of root biomass, shoot biomass, $\mathrm{N}$ content and $\mathrm{N}$ accumulation. When the $\mathrm{F}$ test showed significance by ANOVA, the Tukey test was performed using a 5\% probability level in order to compare means.

\section{Results and Discussion}

\subsection{Weather}

During the ratoon crop cycle evaluated in this study, the ETc distributions (Figure 2) were similar for both sites; however, higher values were obtained for TK than for RE. Overall, ETc increased at the beginning of the cycle (cane-plant harvest) until December at both sites. The ETc declined in January due to high rainfall (which de- 


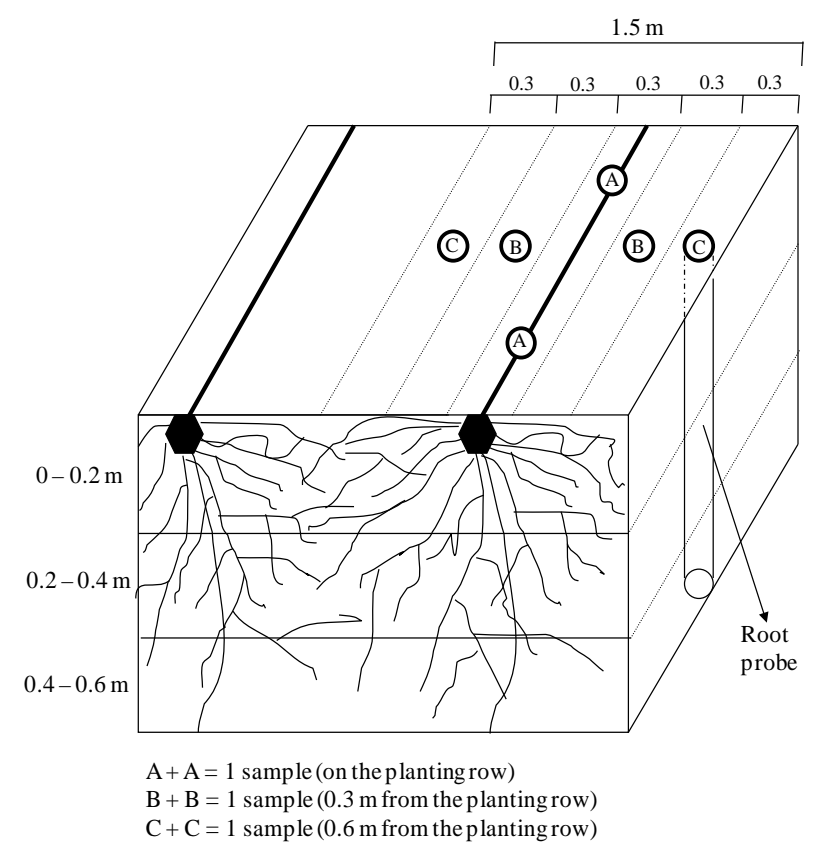

Figure 1. Sugarcane root system sampling method (according to [25]).
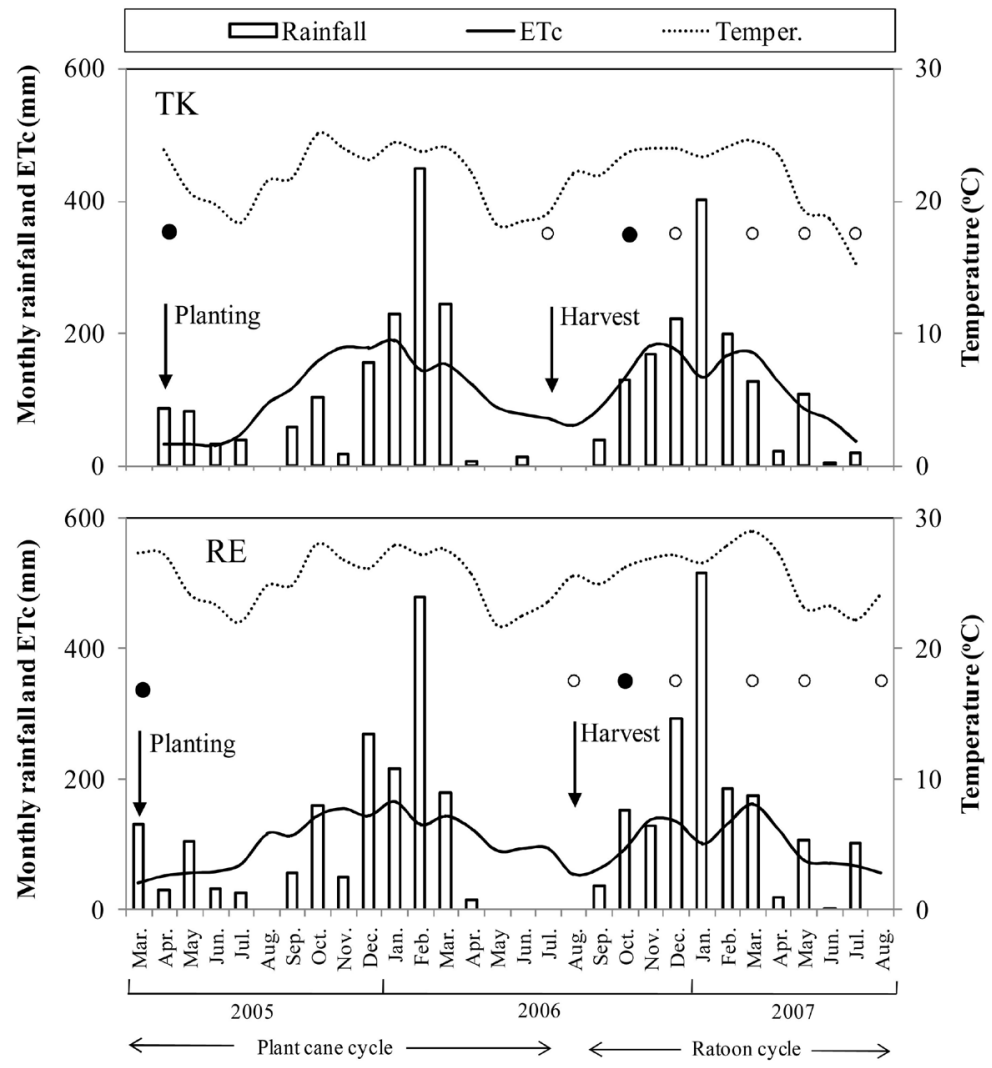

Figure 2. Rainfall, crop evapotranspiration (ETc) and mean temperatures at Typic Kandiudox (TK) and Rhodic Eutrudox (RE) trials over the ratoon crops cycle. The solid circles represent the fertilizer application dates and the open circles represent shoot and root evaluation periods. 
creased radiation), and increased again until March, and thereafter they decreased (Figure 2). ETc reached the highest values between December and February, period with adequate weather conditions for vegetative growth and biomass accumulation. This period encompassed the maximum growth stage of the crop. Overall, the water balance during the ratoon crop cycle is representative of field sugarcane conditions in Southeastern Brazil.

\subsection{Root Density (RD)}

At TK site, $\mathrm{N}$ fertilization showed little effect on sugarcane root growth in the evaluated periods (Figure 3). Differences in root density due to $\mathrm{N}$ application were observed in the superficial soil layer at 225 and 288 dah, with no effect in the remaining periods and soils layers. Greater effects were observed for the dynamics of growth and root death during the cycle, which occurred mainly in the 0 to $20 \mathrm{~cm}$ layer. Similar findings of root turnover were observed by [28].

The root density increased from the cane plant harvest up to 288 dah, decreasing thereafter until the harvest (349 dah). Although the highest root density observed in this study was found in May (288 dah, Figure 3), a previous study of cane plant in the same experimental area found highest root density in December, followed by a decrease until harvest [17]. Additionally, the root density in December in the cane plant cycle was higher than that obtained in the present study. This finding reveals differences in the pattern of root system dynamics in the cane plant and ratoon cane cycles. Probably this difference is related to the dynamics of emergency and death of tillers, which is normally higher in the cane plant cycle, resulting in higher root turnover during the cane plant cycle.

The dynamics of sugarcane root density over the cycle has already been reported. In addition to [28] [29] also observed variations in sugarcane ratoon root density during plant development. These findings suggest that root growth and death are connected to the moist and drought cycles of the soil. In corn, [13] observed that root density increased during the cycle in a drought year, which was not observed in a year with normal rain distribution.

At the RE site, $\mathrm{N}$ fertilization affected the sugarcane root growth more intensively than at $\mathrm{SA}$, including in the cane plant harvest time. On the evaluation at 124 dah, the ratoon $\mathrm{N}$ fertilization increased root density in the three soil layers, and the application of $\mathrm{N}$ at planting had no residual effect in the ratoon cycle (Figure 3). From December to March, there was a reduction in root density, equaling the root density among treatments in March. This may have occurred as a result of competition for shoot growth. There was an increase in root density from March to May. Despite low soil water content from May to August, the root biomass maintained stable until harvest (different from the TK site), possibly due to the atypical rainfall (80 mm on July 2007, Figure 2) that may have supported root growth until harvest. In May and August, the 120 - 0 treatment was associated with lower root density, and it was also the treatment associated with the lowest shoot biomass. At harvest, plants that received $\mathrm{N}$ fertilization in the ratoon ( 0 - 150 and 120 - 150) showed the highest root density in the $0-0.2 \mathrm{~m}$ soil layer, as well as in the 0.2 to $0.4 \mathrm{~m}$ soil layer for the 0 - 150 treatment (Figure 3).

The effect of increasing root density by $\mathrm{N}$ fertilization has previously been reported for other crops. For corn, several studies showed an increase in root density due to the $\mathrm{N}$ fertilization [13]-[15], especially at the beginning of the cycle. In most of those studies, fertilizer treatment promoted a root increase at the site where fertilizer was applied, and this was also observed for a barley crop growing in nutrient solution [16]. However, a negative effect of $\mathrm{N}$ doses on root biomass at harvest time was observed, even with an increase in root length observed during the cycle [13]. For cane plant, [17] observed that $\mathrm{N}$ doses increased the root biomass during the cycle in a Typic Hapludox, although no N effect was found for root growth at the TK site. These results support our observartions, indicating that effect of $\mathrm{N}$ on sugarcane rooting is site-dependent.

Comparing the results obtained in both sites, the root density was higher at TK than at RE (Figure 3). This was certainly due to the better conditions for root growth at TK than at RE site. Conventional tillage (deep plowing, harrowing - twice, and furrowing) was performed at TK site, whereas reduced tillage (chisel plowing, and furrowing) was adopted at RE site. Deeper soil preparation at TK site certainly created better conditions for root growth. One evidence is the high soil density values obtained at the RE site (Table 1) in comparison with other soils with the same texture. This possibly resulted in higher soil penetration resistance at the RE site which decreased root density. There are evidences that high soil strength promote reduced root growth [30] [31]. Similar to our results, [32] also found higher root density in a sandy soil than in a clayey soil. The author found that root biomass for the clayey soil was only $17 \%$ of root biomass for the sandy soil in the plant crop at $250-300$ days of age, increasing to $59 \%$ in the second ratoon. 

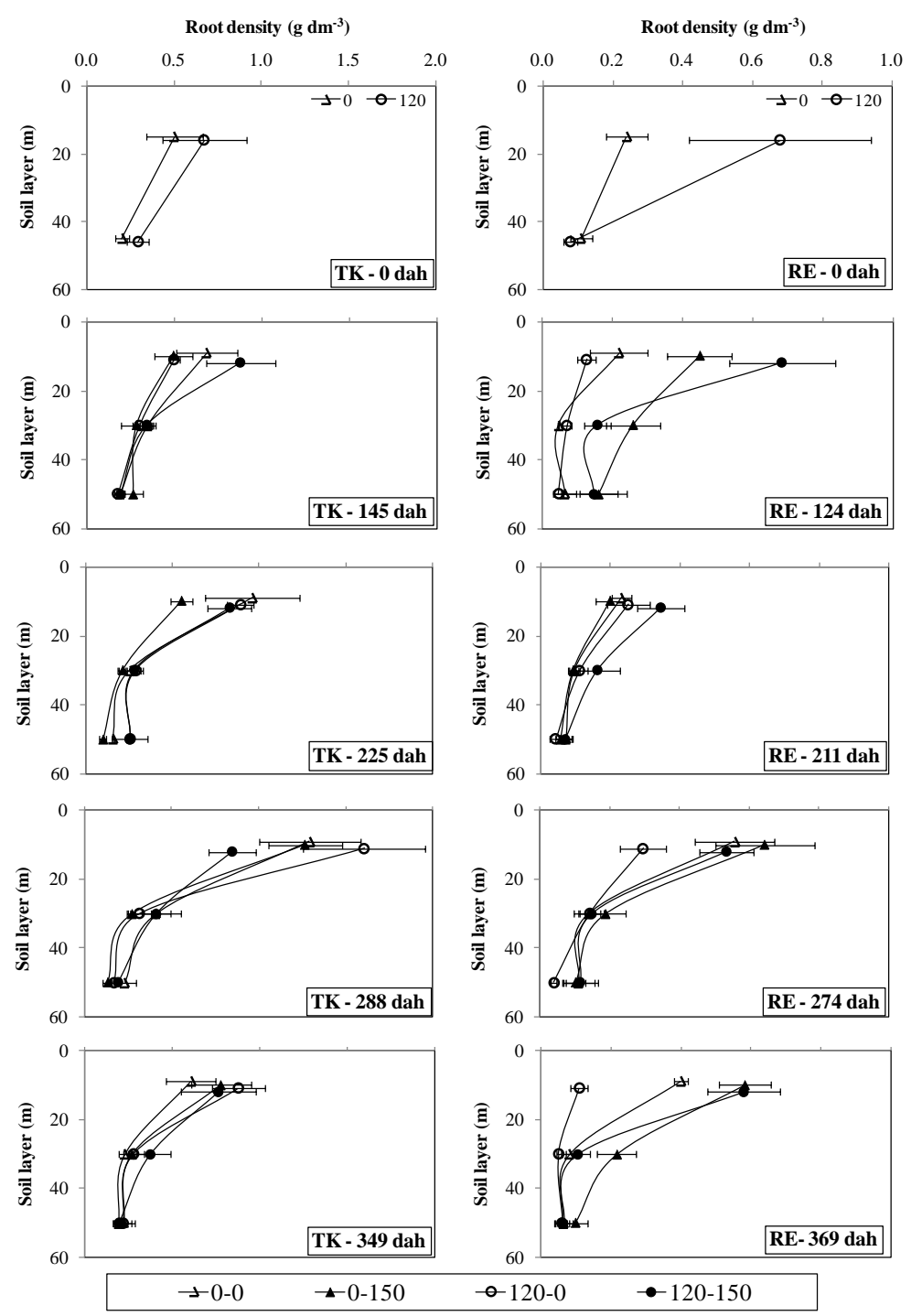

Figure 3. Root density $\left(\mathrm{g} \cdot \mathrm{dm}^{-3}\right)$ throughout the ratoon cycle at Typic Kandiudox (TK) or Rhodic Eutrudox (RE) sites, for the $\mathrm{N}$ fertilization treatments. The bars indicate standard deviation $(\mathrm{n}=4)$.

Analysing the distribution of root system in the soil profile, the $\mathrm{N}$ applied at cane plant $\left(120 \mathrm{~kg} \cdot \mathrm{ha}^{-1} \mathrm{~N}\right)$ resulted in higher root density at cane plant harvest at $0.3 \mathrm{~m}$ from plants at TK site and on the planting row at the $\mathrm{RE}$ site (Table 2). Over the ratoon crop cycle, the $\mathrm{N}$ doses applied both at planting and to the ratoon had no effect on root architecture at TK (Table 2). However, at RE, the ratoon fertilization $\left(150 \mathrm{~kg} \cdot \mathrm{ha}^{-1} \mathrm{~N}\right)$ increased the root density at 0 and $0.3 \mathrm{~m}$ distances from plants in December 2006 (124 dah). This effect disappeared in the two subsequent evaluations (March 2007 and May 2007), and it was observed again only at harvest, in August 2007. The effect of increasing root density at sites where fertilizer was applied has previously been found for other crops [14]. At RE, the root density between rows ( $0.6 \mathrm{~m}$ distance between plants) was much lower than at TK, supporting the hypothesis of restriction to root growth in this soil.

\subsection{Root and Shoot Biomass, and N Accumulation}

At TK site, $\mathrm{N}$ fertilization showed a small effect on biomass, $\mathrm{N}$ content and $\mathrm{N}$ accumulation in the root and shoot compartments over the cycle (Table 3). The main findings were temporal variation on root and shoot biomass. While the higher root biomass was found at 288 dah, the shoot biomass continued increasing through 
Table 2. Sugarcane root density $\left(\mathrm{g} \cdot \mathrm{dm}^{-3}\right)$ over the ratoon crop cycle (dah, days after harvest) as related to distance from sugarcane plants depending to $\mathrm{N}$ fertilization rates ${ }^{\mathrm{a}}$.

\begin{tabular}{|c|c|c|c|c|c|c|c|c|c|c|c|c|}
\hline \multirow{2}{*}{ Treatment $^{b}$} & \multicolumn{6}{|c|}{ Distance (m) } & \multicolumn{6}{|c|}{ Distance (m) } \\
\hline & \multicolumn{2}{|c|}{$\mathbf{0}$} & \multicolumn{2}{|c|}{0.3} & \multicolumn{2}{|c|}{0.6} & \multicolumn{2}{|c|}{$\mathbf{0}$} & \multicolumn{2}{|c|}{0.3} & \multicolumn{2}{|c|}{0.6} \\
\hline & \multicolumn{6}{|c|}{ Typic Kandiudox } & \multicolumn{6}{|c|}{ Rhodic Eutrudox } \\
\hline & \multicolumn{6}{|c|}{ July/06 (0 dah) } & \multicolumn{6}{|c|}{ August/06 (0 dah) } \\
\hline 0 & 0.76 & $(0.19)$ & 0.19 & $(0.03)$ & 0.10 & $(0.02)$ & 0.31 & $(0.07)$ & 0.13 & $(0.04)$ & 0.07 & $(0.03)$ \\
\hline \multirow[t]{2}{*}{120} & 0.98 & $(0.19)$ & 0.33 & $(0.07)$ & 0.14 & $(0.03)$ & 1.00 & $(0.33)$ & 0.13 & $(0.03)$ & 0.02 & $(0.01)$ \\
\hline & \multicolumn{6}{|c|}{ December/06 (145 dah) } & \multicolumn{6}{|c|}{ December/06 (124 dah) } \\
\hline $0-0$ & 0.78 & $(0.36)$ & 0.23 & $(0.07)$ & 0.21 & $(0.05)$ & 0.26 & $(0.17)$ & 0.04 & $(0.03)$ & 0.02 & $(0.01)$ \\
\hline $0-150$ & 0.63 & $(0.21)$ & 0.31 & $(0.10)$ & 0.11 & $(0.04)$ & 0.70 & $(0.24)$ & 0.13 & $(0.06)$ & 0.03 & $(0.01)$ \\
\hline $120-0$ & 0.53 & $(0.11)$ & 0.30 & $(0.10)$ & 0.14 & $(0.07)$ & 0.22 & $(0.08)$ & 0.02 & $(0.01)$ & 0.00 & $(0.00)$ \\
\hline \multirow[t]{2}{*}{$120-150$} & 0.87 & $(0.36)$ & 0.32 & $(0.15)$ & 0.23 & $(0.09)$ & 0.90 & $(0.46)$ & 0.07 & $(0.03)$ & 0.01 & $(0.01)$ \\
\hline & \multicolumn{6}{|c|}{ March/07(225 dah) } & \multicolumn{6}{|c|}{ March/07 (211 dah) } \\
\hline $0-0$ & 0.99 & $(0.65)$ & 0.28 & $(0.08)$ & 0.11 & $(0.04)$ & 0.27 & $(0.10)$ & 0.09 & $(0.03)$ & 0.04 & $(0.02)$ \\
\hline $0-150$ & 0.61 & $(0.27)$ & 0.18 & $(0.07)$ & 0.08 & $(0.03)$ & 0.22 & $(0.10)$ & 0.09 & $(0.03)$ & 0.04 & $(0.01)$ \\
\hline $120-0$ & 0.99 & $(0.34)$ & 0.29 & $(0.09)$ & 0.15 & $(0.07)$ & 0.24 & $(0.11)$ & 0.10 & $(0.07)$ & 0.05 & $(0.03)$ \\
\hline \multirow[t]{2}{*}{$120-150$} & 0.92 & $(0.39)$ & 0.25 & $(0.12)$ & 0.19 & $(0.04)$ & 0.37 & $(0.16)$ & 0.14 & $(0.06)$ & 0.07 & $(0.03)$ \\
\hline & \multicolumn{6}{|c|}{ May/07 (288 dah) } & \multicolumn{6}{|c|}{ May/07 (274 dah) } \\
\hline $0-0$ & 1.38 & $(0.70)$ & 0.35 & $(0.20)$ & 0.21 & $(0.08)$ & 0.68 & $(0.43)$ & 0.11 & $(0.04)$ & 0.03 & $(0.01)$ \\
\hline $0-150$ & 1.23 & $(0.72)$ & 0.30 & $(0.20)$ & 0.14 & $(0.04)$ & 0.77 & $(0.41)$ & 0.13 & $(0.06)$ & 0.04 & $(0.02)$ \\
\hline $120-0$ & 1.68 & $(1.06)$ & 0.30 & $(0.12)$ & 0.12 & $(0.05)$ & 0.28 & $(0.12)$ & 0.14 & $(0.07)$ & 0.06 & $(0.03)$ \\
\hline \multirow[t]{2}{*}{$120-150$} & 0.98 & $(0.42)$ & 0.31 & $(0.13)$ & 0.15 & $(0.06)$ & 0.60 & $(0.31)$ & 0.15 & $(0.04)$ & 0.05 & $(0.02)$ \\
\hline & \multicolumn{6}{|c|}{ July/07(349 dah) } & \multicolumn{6}{|c|}{ August/07 (369 dah) } \\
\hline $0-0$ & 0.61 & $(0.29)$ & 0.22 & $(0.09)$ & 0.19 & $(0.04)$ & 0.48 & $(0.22)$ & 0.06 & $(0.04)$ & 0.01 & $(0.01)$ \\
\hline $0-150$ & 0.77 & $(0.43)$ & 0.35 & $(0.14)$ & 0.14 & $(0.04)$ & 0.74 & $(0.34)$ & 0.13 & $(0.09)$ & 0.02 & $(0.01)$ \\
\hline $120-0$ & 0.96 & $(0.41)$ & 0.28 & $(0.15)$ & 0.13 & $(0.04)$ & 0.13 & $(0.04)$ & 0.07 & $(0.02)$ & 0.03 & $(0.02)$ \\
\hline $120-150$ & 0.86 & $(0.46)$ & 0.33 & $(0.08)$ & 0.14 & $(0.05)$ & 0.63 & $(0.36)$ & 0.07 & $(0.03)$ & 0.04 & $(0.02)$ \\
\hline
\end{tabular}

${ }^{\mathrm{a}}$ Values represent the sum of the root density obtained at depths of 0 to $0.2 \mathrm{~m}, 0.2$ to $0.4 \mathrm{~m}$ and 0.4 to $0.6 \mathrm{~m}$, for each plant distance specified. Values between parenthesis represent the standard deviation $(n=4)$. ${ }^{\mathrm{b}}$ The first values $(0$ or 120$)$ indicate the $\mathrm{N}$ dose at planting and the second values $(0$ or 150) indicate the $\mathrm{N}$ dose to the ratoon, in $\mathrm{kg} \cdot \mathrm{ha}^{-1}$.

the cycle. Despite the increasing shoot biomass accumulation, the $\mathrm{N}$ accumulation on shoot was similar between 225 and 288 dah, probably because the stage of leaf senescence and maturation. At RE site, ratoon $\mathrm{N}$ fertilization increased biomass and $\mathrm{N}$ accumulation on roots at 0, 124 and 369 dah (Table 4). Ratoon $\mathrm{N}$ fertilization increased shoot biomass at 211 and 369 dah and $\mathrm{N}$ accumulation on shoot in all periods. This shows that increasing the root system was connected with highest $\mathrm{N}$ absorption by the plants, as observed for corn [15].

Although no effect of planting or ratoon fertilization was observed in undergournd stem components (mass, content and $\mathrm{N}$ accumulation), this compartment accumulated about $20 \mathrm{~kg} \cdot \mathrm{ha}^{-1} \mathrm{~N}$, which is higher than the amount accumulated into the roots, proving to be an important source of $\mathrm{N}$ for the subsequent regrowth. However, opposite to the findings of [20], the results presented in Table 3 and Table 4 do not support the hypothesis that high $\mathrm{N}$ rates will increase root growth and $\mathrm{N}$ stored in roots.

The effects of $\mathrm{N}$ addition on shoot growth and $\mathrm{N}$ accumulation were variable between sites (Table 3, Table 4). The main findings were temporal variation in root and shoot biomass. The effects of $\mathrm{N}$ fertilizer addition on those parameters ocurred mainly at the beginning of the cycle and disappeared with sugarcane aging. This comportment can be explained, at least in part, by the findings of [33], in which the amount of $\mathrm{N}$ derived from fertilizer in sugarcane is higher in the initial stages of sugarcane development, decreasing with sugarcane aging due to the increasingly share of $\mathrm{N}$ derived from soil $\mathrm{N}$ mineralization.

While inorganic fertilizer $\mathrm{N}$ provides an immediate source of mineral $\mathrm{N}$ for the crop, the majority of $\mathrm{N}$ in the crop is often derived from $\mathrm{N}$ stored in the soil organic matter [34]. Since the soil is the main source of $\mathrm{N}$ for the crops through soil $\mathrm{N}$ mineralization, it is expected that sugarcane will show a small effect of $\mathrm{N}$ fertilization when 
Table 3. Biomass, $\mathrm{N}$ content and $\mathrm{N}$ accumulation in the plant compartments (roots, stool and shoot) over the first ratoon crop cycle according to the planting (residual effect) and ratoon $\mathrm{N}$ fertilization. Typic Kandiudox site.

\begin{tabular}{|c|c|c|c|c|c|c|c|c|c|c|}
\hline \multirow{2}{*}{ Treatment $^{\mathrm{a}}$} & \multicolumn{5}{|c|}{ Days after harvest } & \multicolumn{5}{|c|}{ Days after harvest } \\
\hline & $\mathbf{0}$ & 145 & 225 & 288 & $349^{b}$ & $\mathbf{0}$ & 145 & 225 & 288 & 349 \\
\hline & \multicolumn{5}{|c|}{ Roots $^{c}$} & \multicolumn{5}{|c|}{ Shoot $^{\mathrm{c}}$} \\
\hline & \multicolumn{10}{|c|}{ Biomass $\left(\mathbf{t} \cdot \mathbf{h a}^{-1}\right)$} \\
\hline $0-0$ & $1.61 \mathrm{a}$ & $1.99 \mathrm{a}$ & $2.11 \mathrm{a}$ & 3.55 a & 1.73 a (5.17 a) & - & $5.51 \mathrm{a}$ & 20.28 a & $27.83 \mathrm{~b}$ & $39.36 \mathrm{a}$ \\
\hline $0-150$ & $1.61 \mathrm{a}$ & 1.68 a & $1.35 \mathrm{a}$ & $2.54 \mathrm{~b}$ & 2.11 a (4.32 a) & - & 9.94 a & 22.62 a & 29.89 b & $40.50 \mathrm{a}$ \\
\hline $120-0$ & $2.29 \mathrm{a}$ & $1.83 \mathrm{a}$ & $2.26 \mathrm{a}$ & $3.75 \mathrm{a}$ & $2.13 \mathrm{a}(4.52 \mathrm{a})$ & - & $8.52 \mathrm{a}$ & 18.90 a & 35.55 a & $40.84 \mathrm{a}$ \\
\hline $120-150$ & $2.29 \mathrm{a}$ & $2.35 \mathrm{a}$ & $2.16 \mathrm{a}$ & $2.56 \mathrm{~b}$ & 2.16 a (4.35 a) & - & $6.44 \mathrm{a}$ & $18.24 \mathrm{a}$ & $26.60 \mathrm{~b}$ & $39.92 \mathrm{a}$ \\
\hline \multirow[t]{2}{*}{ Average } & $1.95 \mathrm{~B}$ & $1.97 \mathrm{~B}$ & $1.97 \mathrm{~B}$ & $3.10 \mathrm{~A}$ & $2.03 \mathrm{~B}$ & & $7.60 \mathrm{D}$ & $20.01 \mathrm{C}$ & 29.97 B & $40.15 \mathrm{~A}$ \\
\hline & \multicolumn{10}{|c|}{$\mathrm{N}$ content $\left(\mathrm{g} \cdot \mathrm{kg}^{-1} \mathrm{~N}\right)$} \\
\hline $0-0$ & $4.75 \mathrm{a}$ & $3.78 \mathrm{a}$ & $4.90 \mathrm{a}$ & 3.58 a & 4.58 a (4.00 a) & - & $9.38 \mathrm{~b}$ & $4.53 \mathrm{~b}$ & 3.68 a & $3.10 \mathrm{a}$ \\
\hline $0-150$ & $4.75 \mathrm{a}$ & $4.48 \mathrm{a}$ & $4.88 \mathrm{a}$ & $4.55 \mathrm{a}$ & $5.20 \mathrm{a}(4.48 \mathrm{a})$ & - & $10.40 \mathrm{ab}$ & $4.33 \mathrm{~b}$ & $3.33 \mathrm{a}$ & 3.17 a \\
\hline $120-0$ & $4.98 \mathrm{a}$ & $3.20 \mathrm{a}$ & $3.73 \mathrm{ab}$ & $3.40 \mathrm{a}$ & 5.03 a (4.45 a) & - & $9.85 b$ & $5.43 \mathrm{ab}$ & 3.68 a & 3.15 a \\
\hline $120-150$ & $4.98 \mathrm{a}$ & 3.35 a & $3.40 \mathrm{~b}$ & $4.08 \mathrm{a}$ & 4.68 a (3.95 a) & - & 11.10 a & $6.40 \mathrm{a}$ & $3.48 \mathrm{a}$ & $3.31 \mathrm{a}$ \\
\hline \multirow[t]{2}{*}{ Average } & $4.86 \mathrm{~A}$ & $3.70 \mathrm{~B}$ & $4.23 \mathrm{AB}$ & $3.90 \mathrm{~B}$ & $4.87 \mathrm{~A}$ & & $10.18 \mathrm{~A}$ & $5.17 \mathrm{~B}$ & $3.54 \mathrm{C}$ & $3.18 \mathrm{C}$ \\
\hline & \multicolumn{10}{|c|}{$\mathrm{N}$ accumulation $\left(\mathbf{k g} \cdot \mathrm{ha}^{-1} \mathrm{~N}\right)$} \\
\hline $0-0$ & $7.58 \mathrm{a}$ & $7.56 \mathrm{a}$ & 9.99 a & 12.83 a & 7.95 a (20.64 a) & - & $50.94 \mathrm{c}$ & 92.26 a & $102.07 \mathrm{~b}$ & $122.51 \mathrm{a}$ \\
\hline $0-150$ & $7.58 \mathrm{a}$ & 7.45 a & $6.60 \mathrm{a}$ & 11.53 a & 10.91 a (19.66 a) & - & 103.50 a & 97.68 a & $99.45 \mathrm{~b}$ & $128.49 \mathrm{a}$ \\
\hline $120-0$ & 11.16 a & $5.88 \mathrm{a}$ & $8.52 \mathrm{a}$ & $12.84 \mathrm{a}$ & 10.59 a (19.95 a) & - & $82.67 \mathrm{ab}$ & $101.25 \mathrm{a}$ & 130.57 a & $142.10 \mathrm{a}$ \\
\hline $120-150$ & 11.16 a & $7.71 \mathrm{a}$ & $7.20 \mathrm{a}$ & 10.28 a & 10.07 a (16.92 a) & - & 71.30 bc & 115.85 a & 91.81 b & $137.25 \mathrm{a}$ \\
\hline Average & $9.37 \mathrm{AB}$ & $7.15 \mathrm{~B}$ & 8.08 B & $11.87 \mathrm{~A}$ & $9.88 \mathrm{AB}$ & & $77.10 \mathrm{C}$ & $101.76 \mathrm{~B}$ & $105.98 \mathrm{~B}$ & $132.59 \mathrm{~A}$ \\
\hline
\end{tabular}

${ }^{\mathrm{a}}$ The first values ( 0 or 120 ) indicate $\mathrm{N}$ dose at planting and the second values ( 0 or 150$)$ indicate $\mathrm{N}$ dose applied to the ratoon, in $\mathrm{kg} \cdot \mathrm{ha}^{-1}$; ${ }^{\mathrm{b}} \mathrm{Values}$ in parenthesis refer to underground stem components (stool); ${ }^{\mathrm{C} V a l u e s}$ followed by the same small letters in column indicates no differences in each parameter between treatments, while different capital letter in line indicate differences between days of cycle for each parameter in the $5 \%$ significance by the Tukey test.

Table 4. Biomass, $\mathrm{N}$ content and $\mathrm{N}$ accumulation in the plant compartments (roots, stool and shoot) over the first ratoon crop cycle according to the planting (residual effect) and ratoon $\mathrm{N}$ fertilization. Rhodic Eutrudox site.

\begin{tabular}{|c|c|c|c|c|c|c|c|c|c|c|}
\hline \multirow{2}{*}{ Treatment $^{\mathrm{a}}$} & \multicolumn{5}{|c|}{ Days after harvest } & \multicolumn{5}{|c|}{ Days after harvest } \\
\hline & $\mathbf{0}$ & 124 & 211 & 274 & $369^{b}$ & $\mathbf{0}$ & 124 & 211 & 274 & $369^{\ddagger}$ \\
\hline & \multicolumn{5}{|c|}{ Roots $^{c}$} & \multicolumn{5}{|c|}{ Shoot ${ }^{\mathrm{c}}$} \\
\hline & \multicolumn{10}{|c|}{ Biomass $\left(\mathbf{t} \cdot \mathrm{ha}^{-1}\right)$} \\
\hline $0-0$ & $0.87 \mathrm{~b}$ & $0.47 \mathrm{~b}$ & $0.62 \mathrm{a}$ & $1.14 \mathrm{a}$ & $0.75 \mathrm{~b}(2.96 \mathrm{a})$ & - & $3.54 \mathrm{a}$ & $14.41 \mathrm{ab}$ & 23.17 a & $33.42 \mathrm{a}$ \\
\hline $0-150$ & $0.87 \mathrm{~b}$ & $1.23 \mathrm{a}$ & $0.57 \mathrm{a}$ & $1.32 \mathrm{a}$ & 1.26 a (2.98 a) & - & $3.91 \mathrm{a}$ & $16.03 \mathrm{ab}$ & $21.50 \mathrm{a}$ & 34.77 a \\
\hline $120-0$ & $1.55 \mathrm{a}$ & $0.32 \mathrm{~b}$ & $0.73 \mathrm{a}$ & $0.91 \mathrm{a}$ & $0.36 \mathrm{~b}(2.79 \mathrm{a})$ & - & $2.33 \mathrm{a}$ & $12.84 \mathrm{~b}$ & $20.53 \mathrm{a}$ & $29.09 \mathrm{~b}$ \\
\hline $120-150$ & $1.55 \mathrm{a}$ & $1.06 \mathrm{a}$ & $0.93 \mathrm{a}$ & $1.20 \mathrm{a}$ & 1.03 a (3.26 a) & - & $3.27 \mathrm{a}$ & $17.43 \mathrm{a}$ & 20.08 a & $31.92 \mathrm{ab}$ \\
\hline \multirow[t]{2}{*}{ Average } & $1.21 \mathrm{~A}$ & $0.77 \mathrm{C}$ & $0.72 \mathrm{C}$ & $1.14 \mathrm{AB}$ & $0.85 \mathrm{BC}$ & & $3.26 \mathrm{D}$ & $15.18 \mathrm{C}$ & $21.32 \mathrm{~B}$ & $32.30 \mathrm{~A}$ \\
\hline & \multicolumn{10}{|c|}{$N$ content $\left(g \cdot \mathrm{kg}^{-1} \mathrm{~N}\right)$} \\
\hline $0-0$ & $3.70 \mathrm{a}$ & $3.23 \mathrm{a}$ & $4.08 \mathrm{a}$ & $3.80 \mathrm{a}$ & $4.20 \mathrm{~b}(4.53 \mathrm{a})$ & - & $10.55 \mathrm{~b}$ & $4.23 \mathrm{~b}$ & $2.90 \mathrm{a}$ & $3.02 \mathrm{a}$ \\
\hline $0-150$ & $3.70 \mathrm{a}$ & $3.40 \mathrm{a}$ & $4.53 \mathrm{a}$ & $3.95 \mathrm{a}$ & $4.25 \mathrm{~b}(4.75 \mathrm{a})$ & - & $12.55 \mathrm{a}$ & $5.47 \mathrm{ab}$ & $3.23 \mathrm{a}$ & $3.28 \mathrm{a}$ \\
\hline $120-0$ & $4.20 \mathrm{a}$ & 3.98 a & $4.65 \mathrm{a}$ & $4.38 \mathrm{a}$ & $4.20 \mathrm{~b}(4.20 \mathrm{a})$ & - & $12.53 \mathrm{a}$ & $6.03 \mathrm{a}$ & $2.80 \mathrm{a}$ & $3.43 \mathrm{a}$ \\
\hline $120-150$ & $4.20 \mathrm{a}$ & $3.35 \mathrm{a}$ & $4.45 \mathrm{a}$ & $4.30 \mathrm{a}$ & 5.43 a (5.35 a) & - & $12.48 \mathrm{a}$ & $5.08 \mathrm{ab}$ & $3.35 \mathrm{a}$ & $3.51 \mathrm{a}$ \\
\hline \multirow[t]{2}{*}{ Average } & $3.95 \mathrm{BC}$ & $3.49 \mathrm{C}$ & $4.43 \mathrm{AB}$ & $4.11 \mathrm{~A}$ & $4.52 \mathrm{~A}$ & & $12.03 \mathrm{~A}$ & $5.20 \mathrm{~B}$ & $3.07 \mathrm{C}$ & $3.31 \mathrm{C}$ \\
\hline & \multicolumn{10}{|c|}{$\mathrm{N}$ accumulation $\left(\mathrm{kg} \cdot \mathrm{ha}^{-1} \mathrm{~N}\right)$} \\
\hline $0-0$ & $3.21 \mathrm{~b}$ & $1.53 \mathrm{~b}$ & $2.44 \mathrm{a}$ & $4.26 \mathrm{a}$ & $3.08 \mathrm{~b}(13.07 \mathrm{a})$ & - & $36.82 \mathrm{~b}$ & $60.97 \mathrm{c}$ & $66.82 \mathrm{a}$ & $101.01 \mathrm{~b}$ \\
\hline $0-150$ & $3.21 \mathrm{~b}$ & $4.20 \mathrm{a}$ & $2.57 \mathrm{a}$ & $5.18 \mathrm{a}$ & 5.44 a (13.75 a) & - & 48.32 a & $87.44 \mathrm{a}$ & $70.10 \mathrm{a}$ & $113.54 \mathrm{a}$ \\
\hline $120-0$ & $6.51 \mathrm{a}$ & $1.26 \mathrm{~b}$ & $3.37 \mathrm{a}$ & $3.93 \mathrm{a}$ & $1.50 \mathrm{~b}(11.51 \mathrm{a})$ & - & $27.78 \mathrm{c}$ & $77.30 \mathrm{~b}$ & $57.62 \mathrm{~b}$ & $99.76 \mathrm{~b}$ \\
\hline $120-150$ & $6.51 \mathrm{a}$ & $3.42 \mathrm{a}$ & $4.16 \mathrm{a}$ & $5.14 \mathrm{a}$ & $5.57 \mathrm{a}(16.42 \mathrm{a})$ & - & $40.18 \mathrm{ab}$ & $87.56 \mathrm{a}$ & $67.25 a$ & $111.95 \mathrm{a}$ \\
\hline Average & $4.86 \mathrm{~A}$ & $2.60 \mathrm{C}$ & 3.13 BC & $4.63 \mathrm{~A}$ & $3.90 \mathrm{AB}$ & & $38.27 \mathrm{D}$ & 78.32 B & $65.45 \mathrm{C}$ & 106.56 A \\
\hline
\end{tabular}

${ }^{\mathrm{a}}$ The first values ( 0 or 120 ) indicate $\mathrm{N}$ dose at planting and the second values ( 0 or 150 ) indicate $\mathrm{N}$ dose applied to the ratoon, in $\mathrm{kg} \cdot \mathrm{ha}^{-1}$; ${ }^{\mathrm{b}} \mathrm{Values}$ in parenthesis refer to underground stem components (stool); ${ }^{\mathrm{C} V a l u e s}$ followed by the same small letters in column indicates no differences in each parameter between treatments, while different capital letter in lines indicate differences between days of cycle for each parameter in the $5 \%$ significance by the Tukey test. 
the root system utilizes the soil profile effectively. As expected, in the soil with better conditions for root system development-promoted by the deep plowing, lower clay content and lower soil resistance to root penetration (TK site), ratoon $\mathrm{N}$ fertilization showed a small effect on root system development, resulting in the absence of fertilizer effect on shoot growth and $\mathrm{N}$ accumulation. On the other hand, in the soil with restricted root system development-associated with a reduced tillage system, high clay content, and evidences of high soil resistance to root penetration (RE site), ratoon $\mathrm{N}$ fertilization showed a significant effect on root system development and consequently on shoot $\mathrm{N}$ accumulation. According to our survey no previous studies reported relationship between root system development and response of crops to $\mathrm{N}$.

\subsection{Root: Shoot Ratio}

The root: shoot ratio was greater at the beginning of the cycle and decreased with sugarcane aging (Figure 4). This trend suggests that plants maintained the root biomass at the beginning of the cycle, supporting a small amount of aboveground biomass. From 124 dah at RE and 145 dah at TK, the aboveground biomass increased consistently (Table 3 and Table 4) and, due to little variation on root biomass over the cycle, the root: Shoot ratio decreased until the harvest. The results show the allocation of photo assimilates for roots maintainance at the beginning of the ratoon cycle and for shoot growth in the remaining period. This pattern is supported by the literature, since as with other Gramineae, the root: shoot ratio for sugarcane is higher during the beginning of the cycle and decreases until harvest [3].

At the RE site, ratoon $\mathrm{N}$ fertilization increased the root: shoot ratio at the beginning of the cycle (Figure 4). This was due to $\mathrm{N}$ effect on root biomass in that period. With sugarcane aging the effect disappeared and, from 211 dah, the root: shoot ratio was similar among treatments. Overall, for both areas the root: shoot ratio reached values between 0.15 to $0.40 \mathrm{~kg} \cdot \mathrm{kg}^{-1}$ around $125-145 \mathrm{dah}$ and, at harvest, between $0.05 \mathrm{~kg} \cdot \mathrm{kg}^{-1}$. In sugarcane grown under potted conditions, a root: shoot ratio of approximately $0.42 \mathrm{~kg} \cdot \mathrm{kg}^{-1}$ at 50 days of the cycle was observed [35], decreasing to $0.15 \mathrm{~kg} \cdot \mathrm{kg}^{-1}$ at 200 days of the cycle; the latter was slightly higher than the values obtained under field conditions in this study.

\section{Conclusion}

The shift from burned to unburned harvest of sugarcane in Brazil resulted in increases in nitrogen fertilization rates. A positive effect on shoot biomass is often reported, but the effect on root architecture and biomass is unknow. Our results show that application of $\mathrm{N}$ fertilizer over the trash temporarily increases root density in the place where fertilizer was applied, but the effect was variable between sites. Under field conditions evaluated in this study, the effect of $\mathrm{N}$ addition in root biomass, shoot biomass and $\mathrm{N}$ accumulation was limited and do not support the hypothesis that high $\mathrm{N}$ rates will increases sugarcane root growth and $\mathrm{N}$ stored in roots. More studied are needed to clarify the advantages of using higher $\mathrm{N}$ rates in unburned sugarcane fields in Brazil.

\section{Acknowledgements}

To Sao Paulo Research Foundation (FAPESP—grant \#2002/20.53408 and grant \#2008/01217-5). To Santa Ade-

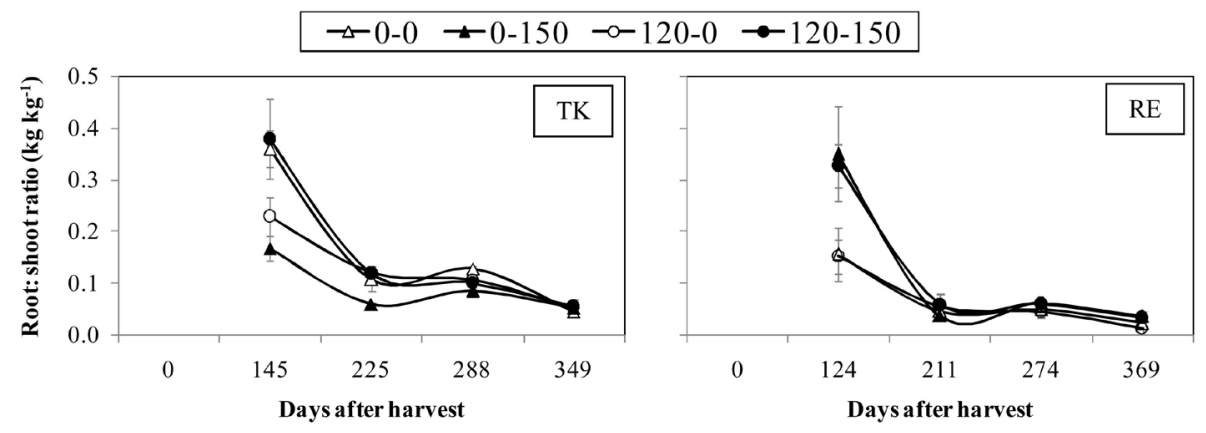

Figure 4. Dynamics of root: Shoot ratios over the first ratoon cycle at the Typic Kandiudox (TK) and Rhodic Eutrudox (RE) sites, depending on $\mathrm{N}$ fertilization rates at planting (0 or 120 $\left.\mathrm{kg} \cdot \mathrm{ha}^{-1} \mathrm{~N}\right)$ or during the ratoon cycle $\left(0\right.$ or $\left.150 \mathrm{~kg} \cdot \mathrm{ha}^{-1} \mathrm{~N}\right)$. Bars represent standard deviations $(n=4)$. 
lia and Sao Martinho Mills as well as the Sugarcane Research Center (CTC) for their operational support.

\section{References}

[1] Vries, S.C., van de Vem, G.W.J., van Ittersum, M.K. and Giller, K.E. (2010) Resource Use Efficiency and Environmental Performance of Nine Major Biofuel Crops, Processed by First-Generation Conversion Techniques. Biomass and Bioenergy, 34, 588-601. http://dx.doi.org/10.1016/j.biombioe.2010.01.001

[2] FAOSTAT (2014) Food and Agriculture Organization of the United Nations. http://faostat.fao.org/site/567/default.aspx\#ancor

[3] Smith, D.M., Inman-Bamber, N.G. and Thorburn, P.J. (2005) Growth and Function of the Sugarcane Root System. Field Crops Research, 92, 169-183. http://dx.doi.org/10.1016/j.fcr.2005.01.017

[4] Matsuoka, S. and Garcia, A.A.F. (2011) Sugarcane underground Organs: Going Deep for Sustainable Production. Tropical Plant Biology, 4, 22-30. http://dx.doi.org/10.1007/s12042-011-9076-3

[5] Chopart, J.L., Rodrigues, S.R., Azevedo, M.C.B. and Medina, C.C. (2009) Estimating Sugar-Cane Root Length Density through Root Maping and Orientation Modelling. Plant and Soil, 313, 101-112. http://dx.doi.org/10.1007/s11104-008-9683-4

[6] Rossetto, R., Dias, F.L.F., Landell, M.G.A., Cantarella, H., Tavares, S., Vitti, A.C. and Perecin, D. (2010) N and K Fertilization of Sugarcane Ratoons Harvested without Burning. Proceedings of International Society Sugar Cane Technology, 27, 1-8.

[7] Hutchings, M.J. and John, E.A. (2003) Distribution of Roots in Soil, and Root Foraging Activity. In: de Kroon, H. and Visser, E.J., Eds., Root Ecology, Springer-Verlag, Berlin, 33-60. http://dx.doi.org/10.1007/978-3-662-09784-7_2

[8] Zhang, H.M., Rong, H. and Pilbeam, D. (2007) Signaling Mechanisms Underlying the Morphological Responses of the Root System to Nitrogen in Arabidopsis Thaliana. Journal of Experimental Botany, 58, 2329-2338. http://dx.doi.org/10.1093/jxb/erm114

[9] Jing, J., Rui, Y., Zhang, F., Rengel, Z. and Shen, J. (2010) Localized Application of Phosphorus and Ammonium Improves Growth of Maize Seedlings by Stimulating Root Proliferation and Rhizosphere Acidification. Field Crops Research, 119, 335-364. http://dx.doi.org/10.1016/j.fcr.2010.08.005

[10] Li, H., Zhang, F. and Shen, J. (2012) Contribution of Root Proliferation in Nutrient-Rich Soil Patches to Nutrient Uptake and Growth of Maize. Pedosphere, 22, 776-784. http://dx.doi.org/10.1016/S1002-0160(12)60063-0

[11] Shen, J.B., Yuan, L.X., Zhang, J.L., Li, H.G., Bai, Z.H., Chen, X.P., Zhang, W.F. and Zhang, F.S. (2011) Phosphorus Dynamics: From Soil to Plant. Plant Physiology, 156, 997-1005. http://dx.doi.org/10.1104/pp.111.175232

[12] Li, H., Ma, Q., Li, H., Zhang, F., Rengel, Z. and Shen, J. (2014) Root Morphological Responses to Localized Nutrient Supply Differ among Crop Species with Contrasting Root Traits. Plant and Soil, 376, 151-163. http://dx.doi.org/10.1007/s11104-013-1965-9

[13] Anderson, E.L. (1987) Corn Root Growth and Distribution as Influenced by Tillage and Nitrogen Fertilization. Agronomy Journal, 79, 544-549. http://dx.doi.org/10.2134/agronj1987.00021962007900030029x

[14] Anghinoni, I. and Barber, S.A. (1988) Corn Root Growth and Nitrogen Uptake as Affected by Ammonium Placement. Agronomy Journal, 80, 799-802. http://dx.doi.org/10.2134/agronj1988.00021962008000050021x

[15] Mackay, A.D. and Barber, S.A. (1986) Effect of Nitrogen on Root Growth of Two Corn Genotypes in the Field. Agronomy Journal, 78, 699-703. http://dx.doi.org/10.2134/agronj1986.00021962007800040028x

[16] Drew, M.C. (1975) Comparison of the Effects of a Localized Supply of Phosphate, Nitrate, Ammonium and Potassium on the Growth of the Seminal Root System, and the Shoot, in Barley. New Phytologist, 75, 479-490. http://dx.doi.org/10.1111/j.1469-8137.1975.tb01409.x

[17] Otto, R., Franco, H.C.J., Faroni, C.E., Vitti, A.C. and Trivelin, P.C.O. (2009) Sugarcane Root and Shoot Phytomass Related to Nitrogen Fertilization at Planting. Pesquisa Agropecuária Brasileira, 44, 398-405. http://dx.doi.org/10.1590/S0100-204X2009000400010

[18] Sampaio, E.V.S.B., Salcedo, I.H. and Cavalcanti, F.J.A. (1987) Dinâmica de nutrientes em cana-de-açúcar. III: Conteúdo de nutrientes e distribuição radicular no solo. Pesquisa Agropecuária Brasileira, 22, 425-431.

[19] Thorburn, P.J., Dart, I.K., Biggs, I.M., Baillie, C.P., Smith, M.A. and Keating, B.A. (2003) The Fate of Nitrogen Applied to Sugarcane by Trickle Irrigation. Irrigation Science, 22, 201-209. http://dx.doi.org/10.1007/s00271-003-0086-2

[20] Vitti, A.C., Trivelin, P.C.O., Gava, G.J.C., Pennatti, C.P., Bologna, I.R., Faroni, C.E. and Franco, H.C.J. (2007) Produtividade da cana-de-açúcar relacionada ao nitrogênio residual da adubação e do sistema radicular. Pesquisa Agropecuária Brasileira, 42, 249-256. http://dx.doi.org/10.1590/S0100-204X2007000200014

[21] Soil Survey Staff (2010) Keys to Soil Taxonomy. 11th Edition, USDA-Natural Resources Conservation Service, 
Washington DC.

[22] van Raij, B., Andrade, J.C., Cantarella, H. and Quaggio, J.A., Eds. (2001) Análise química para avaliação da fertilidade de solos tropicais. Instituto Agronômico, Campinas, 285 p.

[23] Grossman, R.B. and Reinsch, T.G. (2002) Bulk Density and Linear Extensibility. In: Dane, J.H. and Topp, G.C., Eds., Methods of Soil Analysis: Physical Methods, Part 4, Soil Science Society of America, Madison, 201-228.

[24] Dane, J.H. and Hopmans, J.W. (2002) Pressure Plate Extractor. In: Dane, J.H. and Topp, G.C., Eds., Methods of Soil Analysis: Physical Methods, Part 4, Soil Science Society of America, Madison, 688-690.

[25] Otto, R., Trivelin, P.C.O., Franco, H.C.J., Faroni, C.E. and Vitti, A.C. (2009) Root System Distribution of Sugar Cane as Related to Nitrogen Fertilization, Evaluated by Two Methods: Monolith and Probes. Revista Brasileira de Ciência do Solo, 33, 601-611. http://dx.doi.org/10.1590/S0100-06832009000300013

[26] Malavolta, E., Vitti, G.C. and Oliveira, S.A. (1997) Avaliação do estado nutricional das plantas-princípios e aplicações. 2nd Edition, Potafós, Piracicaba, 309 p.

[27] Allen, R.G., Pereira, L.S., Raes, D. and Smith, M. (1998) Crop Evapotranspiration: Guidelines for Computing Crop Water Requirements. FAO Irrigation and Drainage Paper 56, FAO, Rome, 300 p.

[28] Battie-Laclau, P. and Laclau, J.P. (2009) Growth of the Whole Root System for a Plant Crop of Sugarcane under Rainfed and Irrigated Environments in Brazil. Field Crops Research, 114, 351-360. http://dx.doi.org/10.1016/j.fcr.2009.09.004

[29] Ball-Coelho, B., Sampaio, E.V.S.B., Tiessen, H. and Stewart, J.W.B. (1992) Root Dynamics in Plant and Ratoon Crops of Sugar Cane. Plant and Soil, 142, 297-305. http://dx.doi.org/10.1007/BF00010975

[30] Imhoff, S., Kay, B.D., Silva, A.P. and Hajabbasi, M.A. (2010) Evaluating Responses of Maize (Zea mays L.) to Soil Physical Conditions Using a Boundary Line Approach. Soil and Tillage Research, 106, 303-310. http://dx.doi.org/10.1016/j.still.2009.11.007

[31] Otto, R., Silva, A.P., Franco, H.C.J., Oliveira, E.C.A. and Trivelin, P.C.O. (2011) High Soil Penetration Resistance Reduces Sugarcane Root System Development. Soil and Tillage Research, 117, 201-210. http://dx.doi.org/10.1016/j.still.2011.10.005

[32] Aboyami, Y.A. (1989) Effect of Soil Type and Crop Cycle on Root Development and Distribution Pattern of a Commercial Sugarcane Cultivar under Normal Irrigation and Field Conditions at Bacita Estate, Nigeria. Turrialba, 39, 78-84.

[33] Franco, H.C.J., Otto, R., Faroni, C.E., Vitti, A.C., Oliveira, E.C.A. and Trivelin, P.C.O. (2011) Nitrogen in Sugarcane Derived from Fertilizer under Brazilian Field Conditions. Field Crops Research, 121, 29-41. http://dx.doi.org/10.1016/j.fcr.2010.11.011

[34] Dourado-Neto, D., Powlson, D., Abu Bakar, R., Bacchi, O.O.S., Basanta, M.V., thi Cong, P., et al. (2010) Multiseason Recoveries of Organic and Inorganic Nitrogen-15 in Tropical Cropping Systems. Soil Science Society of America Journal, 74, 139-152. http://dx.doi.org/10.2136/sssaj2009.0192

[35] Smith, J.P. (1998) Studies on the Relation between Root Growth and Shoot Growth of Sugarcane. Ph.D. Thesis, James Cook University, Queensland. 
Scientific Research Publishing (SCIRP) is one of the largest Open Access journal publishers. It is currently publishing more than 200 open access, online, peer-reviewed journals covering a wide range of academic disciplines. SCIRP serves the worldwide academic communities and contributes to the progress and application of science with its publication.

Other selected journals from SCIRP are listed as below. Submit your manuscript to us via either submit@scirp.org or Online Submission Portal.
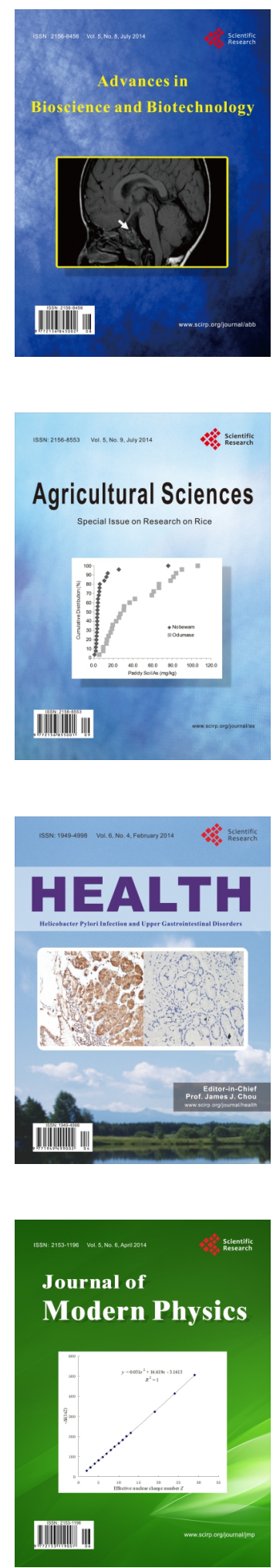
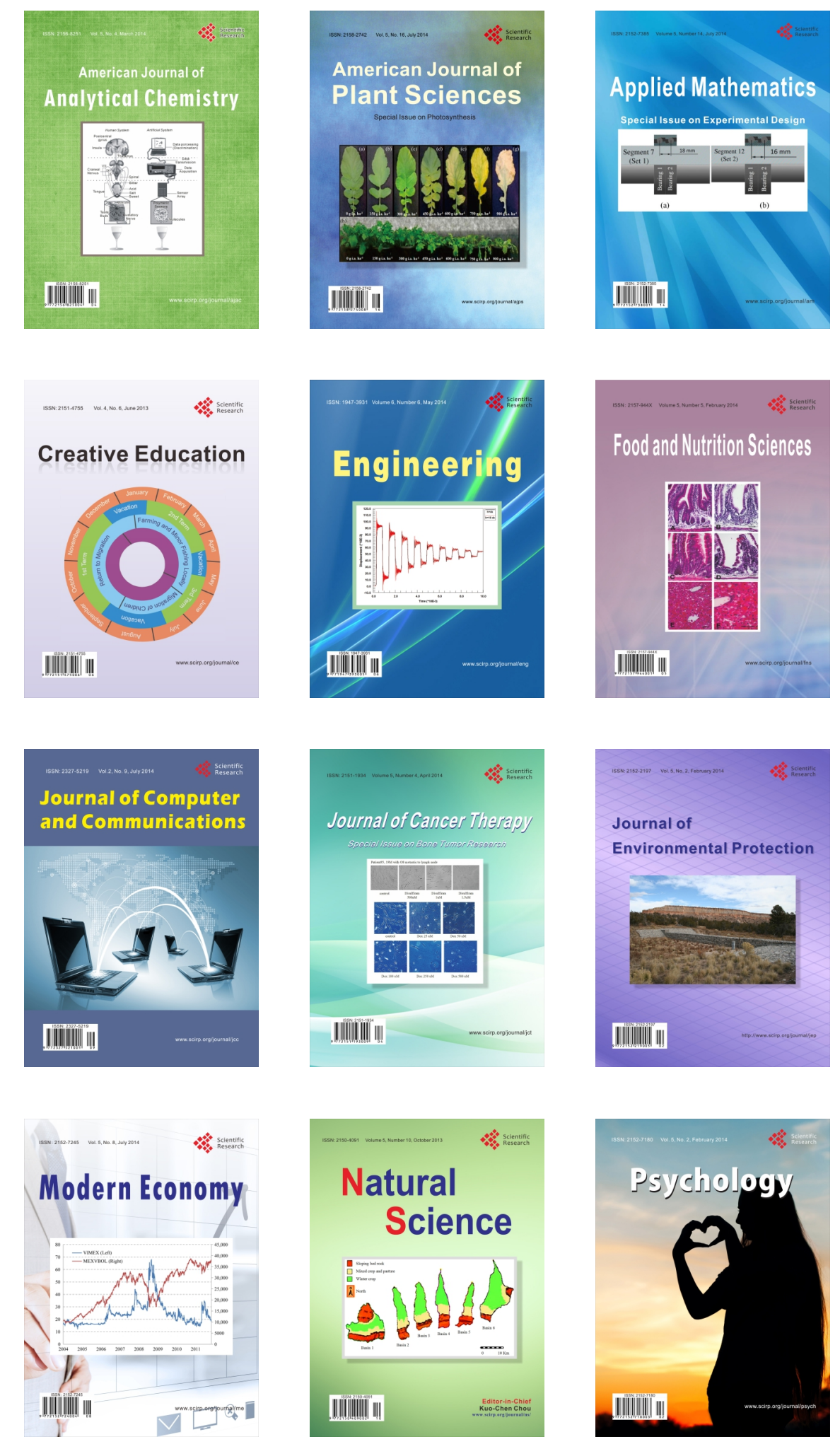